\title{
Anthrovision
}

Vaneasa Online Journal

\section{Visual Anthropology From Latin America: An Introduction}

Carlos Y. Flores and Angela Torresan

\section{Q OpenEdition \\ 1 Journals}

\section{Electronic version}

URL: https://journals.openedition.org/anthrovision/3672

DOI: 10.4000/anthrovision.3672

ISSN: 2198-6754

\section{Publisher}

VANEASA - Visual Anthropology Network of European Association of Social Anthropologists

\section{Electronic reference}

Carlos Y. Flores and Angela Torresan, "Visual Anthropology From Latin America: An Introduction", Anthrovision [Online], 6.2 | 2018, Online since 30 juin 2017, connection on 28 juin 2022. URL: http:// journals.openedition.org/anthrovision/3672 ; DOl: https://doi.org/10.4000/anthrovision.3672

This text was automatically generated on 29 September 2020

(c) Anthrovision 


\title{
Visual Anthropology From Latin America: An Introduction
}

\author{
Carlos Y. Flores and Angela Torresan
}

1 The idea of Latin America as an unified geopolitical entity has been called into question (Mignolo 2005), exposing claims for a specific aesthetics and epistemological modality as romantic fetishism in face of the diverse histories of economic, political, social and population developments (Canclini 1995). How can we then justify a special issue in visual anthropology with a focus on the region? What would it show us beyond a sampling of audio-visual anthropological work produced in and about Latin America? Given the dynamic exchange of technical and intellectual expertise between Latin American visual anthropologists and their counterparts across the globe, how could this regional focus contribute to broader discussions in the discipline? These were the questions we asked ourselves when we were invited to organise a panel on the trends of ethnographic filmmaking in Latin America for the $15^{\text {th }}$ Royal Anthropological Institute Film Festival that took place in Bristol, UK, from 29 March to 1 April 2017. We started from the very broad agenda of examining the intersection between local anthropological work and visualimage production in the region. We ended up, however, with a common denominator, which although it does not encompass all the trends of visual anthropology work in Latin America and is certainly not a prerogative of visual anthropology studies in the region, proved itself to be a constant element that extends beyond the scope of the panel and of this special issue. Visual anthropology from a Latin American perspective is eminently concerned with the political; and it is so because it has been highly influenced not only by certain transnational conversations but, more critically, by local movements of social and political change and resistance.

2 Visual Anthropology has grown exponentially in the last three decades in Latin America with the development of different research and teaching centres within academic institutions in countries, including Brazil, Mexico, Peru, Chile, Ecuador, Colombia and Argentina, expanding to include experimental work made with a wide range of visual media. Our interest here, however, is not to map the teaching and production of visual anthropology in Latin American academic institutions. Rather, our focus is on how visual 
anthropologists have been engaging with and learning from the socio, political, and historical pluralities of voices and places within Latin America in ways that question hegemonic Euro/American-centric anthropological and audio-visual aesthetics and epistemologies. Neither are we interested in setting out a definition for a Latin American visual anthropology based on common themes or on specific theoretical or methodological perspectives or narratives. Our endeavour is necessarily open-ended. We ask what does it mean to think about the production of audio-images from a Latin American perspective - rather than simply made in Latin America? We relate this question to the broader political issues at play in the encounter between anthropology and image-making.

The contributors to this special issue share the basic premise that visual image creation from Latin America anthropology has an intrinsic political epistemology. Paraphrasing Tuhiwai Smith (2012), the emergence of anthropology and ethnographic films and other forms of visual image production in Latin America has not and still is not "an innocent or distant academic exercise, but [rather] an activity that has something at stake..." (p. 5) and takes place within particular geopolitical arrangements. This 'something at stake' is the underlying political angle incidental to practicing anthropology and visual anthropology from a Latin American perspective.

4 The politics of storytelling is here an important point of convergence for approaches that embrace the analytical and political challenge the preposition from provokes. Are ethnographic visual image-makers and scholars creating instances of mutual recognition in Latin America that have political and ethical significance? What can we learn about the intersection between ethnographic visual-making and storytelling from the vantage point of Latin America? We start with a brief overview of the paths anthropology has trodden in the region, which provides the frame of reference for understanding the ongoing commitment that most (visual) anthropologists in Latin America have with the political aspect of their practice.

\section{The Latin American Ethnographic Gaze: An Overview}

5 Anthropology and mechanical image reproduction have been present in Latin America since the start of the twentieth century. The interaction of both fields of praxis were predominantly shaped by colonial frameworks of modern scientific thought and popular imaginaries, which in many ways have been constantly reproduced to the present day. From the beginning of anthropological practice, the symbolic and material construction of a cultural "other" according to Westernised hegemonic codes of understanding not only constructed a separation of worlds between researchers and those studied, but also defined the identities of non-Western groups according to dominant criteria of "objectivity". In Latin America, as in many parts of the world, the modern capacity to comprehend other cultures was, therefore, framed as an exercise of rationalised and observed truth. The convergence of such a scientific enterprise and hegemonic colonial understandings of civilisation impacted not only the colonised population but also shaped the nations built out of the colonies. The very idea of Latin America is, in part, an image of former and current colonial relationships (Said 1978, Mignolo 2005).

One central feature of this process was what has been called indigenismo, a movement whose explicit goal was the defence and national integration of the indigenous population. ${ }^{1}$ As Christian León has signalled, indigenismo represented a particular phase 
of colonial dialectics "in which the coloniser has ceased to be openly racist in order to elaborate an apparently egalitarian and humanistic metaphysics in which conflict is carefully eliminated" (León 2010: 44, our translation). Tobing Rony has observed that in Latin America the "Indian" worked as a cultural metaphor for the projection of alterity, which was not only perceived as savage but also as a figure with positive qualities, such as "authenticity, masculinity, purity, spirituality and an antidote to the ills of modern industrialized capitalism, a myth integrated to the image of the noble savage" (quoted in Grau 2002: 124, 125, our translation). Therefore, the image of the indigenous was at the centre of the colonial project and crucial for the distinct ideologies of the region's post independent nation states.

Within such broader framings, audio-visual representations came to play a fundamental role in the consolidation of this particular understanding of native peoples and their relation with hegemonic modern society. To see social interactions in this way helped local elites, anthropologists amongst them, to determine how to act upon their social reality. During a large part of the twentieth century this involved perceptions of "internal colonialism" in the service of processes of nation-building (Poole 1997, González Casanova 2003, Muratorio 1994). Particularly in the first half of the twentieth century, national non-indigenous elites selected specific indigenous elements to be salvaged and framed them within a series of discourses, institutions and technologies. This, in turn, reinforced the mainstream perception that indigenous people were at once innocence, incompetence, and savage, constructing "an indigenous subject incapable of representing himself and in need of tutelage" (León 2010: 56, our translation, see also Ramos 1998). Mechanical image creation in this context, although imbued with languages of political and disciplinary power, was conceived as a mechanism of truth, due largely to its supposed ability to reproduce an unquestionable reality (Poole 1997, Pinney 1992).

Early examples of visual representations from this perspective can be seen in the anthropological documentary Rituales y Fiestas Bororo (1917), directed by Brazilian army officer Luiz Thomaz Reis, which depicts the process of colonisation of the Amazonia and the symbolic rescue of indigenous people in the process of nation-building in Brazil (Henley 2013). Likewise, Mexican indigenist Manuel Gamio used photography and film between 1917 and 1925 in order to record archaeological excavations in Teotihuacan and at Mayan ruins in Yucatan, together with costumes, dances and songs of those region's inhabitants, although these films are lost today (Novelo 2001). In the following decades, anthropological visual work in Mexico followed a similar pattern and the film that probably best represents the indigenista approach is Todos somos mexicanos (We are all Mexicans), directed by filmmaker José Arenas in1958, which was the first formal documentary of the Instituto Nacional Indigenista (National Indigenist Institute).

9 Visual production of nationalist and indigenous integrationist policies were also evident in other countries in the region in the first half of the twentieth century. Another good example is Peru, where the extraordinary photographic work of Juan Manuel Figueroa Aznar and the Quechua indigenous photographer Martín Chambi drew on specifically Andean aesthetics in order to underline the importance of indigenous culture on the national imaginary (Cánepa 2011). In the 1950s, Bolivian filmmaker Jorge Ruiz followed a similar route with his docu-fiction Vuelve Sebastiana (Come Back Sebastiana - 1953), which depicts the harsh conditions and social marginality of a Chipaya girl and her community.

Such association between images of indigenous people created by agents engaged in different projects of nation-building in Latin America lies at the heart of anthropology 
and ethnographic image-making in the region. Both practices were modernist projects in the colonial sense of building the edifice of Western civilisation on top of the contrasting vision of the Other who lies outside. The Other of Latin America's new nations were located within the national borders, and the frontier between barbarians and civilised had to be drawn if the creole and mestizo elites were to maintain the apparatus of internal colonial privilege.

\section{The Crisis of Representation and Collaborative Practices}

11 A good deal of Latin American movements for social change and self-determination inspired by the Cuban Revolution of 1959 came to mark the second half of the twentieth century. Highly contested politics produced significant shifts in mainstream anthropological practice in the region, which started to question the role anthropologists played in reproducing internal colonial frameworks. The 1971 document "For the Indigenous Liberation", best known as Declaración de Barbados, is representative of this period. Anthropologists working in the region subscribed to a document in the island of Barbados stating that: "today the anthropologist in Latin America is not the person who treats whole populations as mere objects of study, but rather who sees them as colonized subjects and who commits him or herself to their liberation."2

Together with cameraman Jorge Silva, anthropologist Marta Rodríguez, a former student of French ethnographic filmmaker Jean Rouch, pioneered the translation of this political impetus into several films in the late 1960s that portrayed the abject social conditions of marginalized groups in their native Colombia. Other filmmakers related to anthropological research or working with marginalized communities, such as Jorge Ruiz and Jorge Sanjinés in Bolivia, and Jorge Prelorán in Argentina, also produced a new and creative wave of documentary or fiction films which were critical of the unequal relation between Latin American elites, their national states and the impoverished majorities. Military dictatorship followed in several countries backed by US anti-communist national security doctrine which severely curtailed former initiatives for social change and critical anthropological work and its audio-visual representations as a whole.

The return of democratically elected governments in many Latin American countries in the 1980s and 1990s coincided with new anthropological developments bound up with neoliberal agendas, the intensification of socio-economic globalisation and technological innovation. The new environment meant that most national states, while reducing social spending and widening the gap between poor and rich citizens, transferred state obligations to already impoverished individuals or communities, in areas including health, education, justice and security. In this context, many non-state sponsored social movements and projects arose from the grassroots demanding greater socioeconomic inclusion and participation within their nation-states. One of the most significant events in the political arena was the positioning of indigenous movements and peoples in the frontline of such demands. The awarding of the Nobel Peace prize to a Guatemalan Maya K'iche' woman, Rigoberta Menchú, in 1992, the mostly indigenous Zapatista uprising in Chiapas in 1994, Mexico, and Kayapo Chief Raoni who mobilised musician Sting in the late 1980s to gain international attention for Brazilian indigenous struggles, are examples of indigenous mobilisations that helped to challenge the perception of a passive native and 
opened a way to look at indigenous societies more as dynamic historical subjects (Muratorio 1994).

14 Anthropologists working in the region were also influenced by postmodern, postcolonial and feminist critical discussions that had their roots in northern academia. Such critiques claimed that anthropology had systematically represented reality in a questionable way by constructing images of unified and undifferentiated subjects in culturally homogeneous spaces. It was also said that hegemonic relations of authority and representation had silenced alternative visions and voices favouring the anthropologist and Western points of view, while the mere act of representing others was already acknowledged as a form of domination. As discussions continued, knowledge was increasingly re-evaluated as something political and situated (Lutkehaus and Cool 1999).

All these elements, together with the accessibility of new technologies for communications, provided new opportunities for anthropologists to elaborate projects with communities in a more collaborative fashion. One example was the transference of video technology to indigenous communities for processes of self-representation and political activism. Broader publics started to get to know indigenous collaborative video work from Amazonia, Colombia, Mexico and Bolivia. One of the main achievements of these practices was to find common areas between anthropological research interests and the needs for education, self-determination and cultural resistance of communities. In addition, such collaborative exercises partly challenged a modern idea of citizenship based on an individual relationship with the state and gave increased relevance to collective dimensions, group rights and communal representation in order to defend their socio-cultural needs and to develop educative, political and self-awareness processes (Mora 2014: 62). ${ }^{3}$

Other social subjects rose to the fore in anthropological agendas, including afrodescendant communities, marginalised urban dwellers, environmental activists, movements in defence of territory and cultural and citizenship rights, etc. Such movements have mobilized in favour of demands for economic and sociocultural inclusion within their own territories and countries and to denounce policies of dispossession, racism, displacement/migration, political and criminal terror, and state repression.

17 At the same time, Latin American anthropology in general and audio-visual anthropology in particular have become increasingly interested in working with a plurality of research subjects, with a corresponding reduction of the initial emphasis on "the indigenous". In recent decades there has been an explosion of studies on how culture and society is perceived from different individual standpoints, including novel and experimental reflexive anthropological exercises on the body, the senses, drugs, art, sexuality, soundscapes, etc.

In terms of working with audio-visual resources, the generalised access of digitalisation processes that have been developed since the 1990s together with social media have been crucial in facilitating the irruption of subaltern voices in the field of audio-visual anthropological production in Latin America. This has provided some degree of democratisation of spaces of representation and signals the emergence of global citizens who go beyond the frameworks previously guarded by local elites to project their exercises of self-identity almost instantaneously towards global audiences. Within these new spaces certain elements have constituted game changers, such as the interconnectivity between diverse groups previously kept apart by the dominant media, 
something which in turn provides the possibility of interacting using comments, discussion forums and virtual and global learning. Social media platforms such as YouTube, Facebook, or indigenous film festivals allow fresh social interactions within and across marginalised groups in an exchange where counter-hegemonic epistemologies are circulating much more widely than before (López 1993).

\section{Contemporary Visual Anthropology in Latin America} visual anthropologists. Public universities in particular have to work with fewer resources and academic bureaucracy and peer competition are in many cases hampering efforts to produce more outputs of high quality. Many trained visual anthropologists are not able to secure formal employment at universities or research centres, leading many to abandon academia and pursue their goals in the artistic or activist spheres. The increasing concentration of resources in fewer hands in Latin America has also widened the inequality gap, generating new waves of social instability and political polarisation, which in turn is affecting the ways people in the region do research. This period of massive capital accumulation under weaker national states has generated permanent "states of emergency" (Mbembe and Meijtjes 2003), where criminal and generalised violence increasingly affect the contexts where visual anthropologists work, as is the case in countries such as Mexico, Guatemala, Colombia, and Brazil. Researchers, thus, have been adapting their methodologies and finding innovative ways to work in these new scenarios, while also retaining their focus on wider socio-political issues through examination of specific cases.

\section{Visual Anthropology From Latin America}

21 Despite the immensity of the continent and the diversity of socio-political developments of the countries in Latin America, the practice of anthropology within and outside of academia converge in their critical engagement with current socio and political realities. The visual anthropology presentations we brought together in our panel at the 15th RAI Film Festival in Bristol were only a small, but rich, sample of the variety of applications, both analytical and methodological, visual anthropology enjoys in the continent. Dietrich and Ulfe make this clear in their review of the 'politicised political landscape' ${ }^{\text {' }}$ of anthropology in academic institutions in Peru. Throughout the military and democratic governments and the authoritarian neoliberal regime of president Fujimori, anthropologists took part in a wider intellectual and cultural movement of critical debates and interventionist practices. This was also true in countries like Brazil, Mexico, Colombia and Guatemala. The authors in this special issue show how the growing field of 
visual anthropology has followed in the same footsteps with innovative work that ranges from analyses of artistic production to the making of audio-visual anthropology through a variety of visual media.

Dietrich and Ulfe's focus on what they identify as an established field of research on postconflict memory, following the Peruvian Internal Armed Conflict between 1980 and 2000. They explore how the variety of audio-visual work from traditional wooden panel paintings (tablas), to artistic wooden frames similar to religious altarpieces (retablos), and documentaries produced in collaboration with visual anthropologists, tell stories that challenge and confront official narratives of the conflict. These stories complicate categorical borders between victims and perpetrators typical of public representations, and oppose "institutional silences" that perpetuate hegemonic versions of the armed conflict. Antonio Zirión's contribution adds the idea of hypervisibility to the discussion on silences and invisibilities imposed upon peoples whose stories are pushed aside. This hypervisibility - or image overload ubiquitous to entertainment, advertisement and propaganda media across the planet - works as an ideological strategy of social exclusion that maintains marginal populations invisible. Zamorano, in turn, explores one such process of overvisualisation in which urban middle-class self-defence groups in Mexico re-signified, mobilised and built on traditional images of indigenous movements and revolutionary campesinos in order to legitimise their own vision and mission of selfprotection. Silence is, thus, imposed through a kind of over-exposure that misconstrues representations, intentions and realities in the form of stereotypical simplifications.

Furthermore, by looking at the visual representations self-defence groups disseminated in social media and other digital platforms, Zamorano contends that their reappropriation of indigenous representations not only misrepresents, but also reflects current mainstream neoliberal notions of citizenship - a notion substantiated by the idiom of co-responsibility. Here, subaltern cultures are made visible for reasons that do not advance their claims for justice and recognition by the state in order to regain control over their lives. Rather, images of traditional legal systems or inescapable forms of local justice are turned into politically conservative projects of private neoliberal securitisation.

While Zamorano and Dietrich and Ulfe analyse visual cultural productions within and outside the field of visual anthropology, Zirión, Flores, Torresan, and Murray explore audio-visual projects in which they were directly involved. In fact, Murray writes about the research for an ethno-fiction film that he has not made due to other kinds of silences that tactically create a series of "uncertainties".

The films Zirión made in collaboration with marginalised urban groups (Chido mi Banda, 2001; Voces de la Guerrero, 2004; Fuera de Foco, 2013) are poignant examples of experimental approaches he aligns with the notion of "peripheral cinema". Through these projects, Zirión realised that as visual ethnographers we need to create a practice that enables us to contest hegemonic hypervisuality in order to provoke action and bring about political transformation. Such practice requires us to "exercise and cultivate an increasingly wide and inclusive gaze"5; a peripheral vision (Ginsburg 2010) that allows us to understand what really matters to marginalised others. In line with Dietrich and Ulfe's discussion on anthropology and activism, Zirión mentions the importance of cinema activism to the work of visual anthropologists in Latin America. 

levels and forms of collaboration have been extensively discussed in the field of visual anthropology (Crafton 2004, Battaglia 2012, Elder 1995, Caffé and Hikiji 2012, Ginsburg et al 2002, O'Brian 2014), and we see this diversity also in the projects discussed here. While Dietrich and Ulfe talk about collaborating in bringing to the surface stories that run counter to and challenge hegemonic narratives, and Zirión calls for a collaborative project that can contribute to social change, Flores explores the "complex intercultural interactions" that are often at the core of collaborative projects.

The discovery of an archive of videos filmed by indigenous people showing popular tribunales conducted under Mayan law in Santa Cruz del Quiché, Guatemala, prompted a long process of collaboration between Flores, political anthropologist Rachel Sieder, and Maya K'iche' leaders. In the process, the researchers had to adjust their understandings and interests to those of local leaders. The local authorities sought political legitimation and official recognition for indigenous legal practices in the context of an ineffective and racist national justice system that failed to address local realities. This engendered a collaborative project focused on self-determination and social change that had a very specific objective in mind, but in which multiple and conflicting interpretations of the truth, of 'what really happened', memories, and representations had to be carefully negotiated.

Conflicting views were also part of the collaborative video Torresan produced with a couple of residents in Vidigal, a favela in Rio de Janeiro, Brazil, undergoing the initial stages of gentrification process. However, here collaborators were not concerned with confronting official narratives of favelas or advancing a specific agenda. Rather, they shared the researcher's interest in trying to find out the views other residents of Vidigal had of the changes taking place around them. Confronted with a diversity of socioeconomic conditions, the expression of conflicting desires and imaginations of the future, Torresan draws on the notion of storytelling to emphasize how ethnographic filmmaking, as an intersubjective practice, can bridge the personal and the political. The explorative nature of the short film Guto and Graça, was only possible because the people involved, researcher and protagonists, shared an interest in discovering how external forces of real estate capital expansion were affecting new and long-term residents of Vidigal.

This mutual interest did not transpire in Murray's proposal to make a collaborative fictional film on the 1880 state trial against La Recta Provincia, an organisation of sorcerers that was especially active in the island of Chiloé, Chile. Unlike the other contributors, Murray comes into anthropology from a film-making perspective, which provides a different set of questions concerning the ethics of research and the limits of collaboration. The islanders of Chiloé were not keen on engaging with the collaborative film project Murray had proposed because, as he states, they did not wish to make visible a part of their local practices. Here, silence, invisibility, secret, and uncertainty, as Murray discovered, served as a means of resistance to the kind of modernity that had been disrupting the order of life in the island. For all they knew, Murray's evocative film proposal belonged to that modernity. The only path for a possible collaborative project in the future, Murray recognises, would be through the building of mutual trust. Anthropologists and visual anthropologist working from Latin America would probably add that this mutual trust and reciprocal respect goes hand-in-hand with the political 
dimension of their practices, a dimension that is crucial to the people with whom they collaborate.

As Dietrich and Ulfe conclude in their contribution, political commitment has always been an important part of the work of anthropologists and visual anthropologists in Latin America. The "peripheral gaze" we have been cultivating, to borrow from Zirión, the kinds of bridges between the personal and the political that we have been trying to forge, the actual practice of shared anthropology and intersubjective storytelling, offer invaluable contributions to urgent debates on the decolonisation of academic practice and theory (Mignolo 2005) that currently haunt the neoliberal academic landscape.

\section{BIBLIOGRAPHY}

Books and articles

Battaglia, Giulia (2012). Persistence Resistance in London. Between Public Intervention and Practitioner-academic Collaboration. Journal of Studies in South Asian Film and Media 3(1): 43-49

Caffé, Carolina and Hikijy. 2014. Film as Shared Ethnography. Vibrant, Virtual Brazilian Anthropology Journal 9(2): 318-343.

Cardús i Font, Laura. 2014. Indigenous Media: from Transference to Appropriation. AnthroVision [Online], 2 (1) https://journals.openedition.org/anthrovision/668 (accessed 17 May 2019).

Canclini, Néstor García. 1995. Hybrid Cultures: Strategies for Entering and Leaving Modernity. Minneapolis, London: University of Minnesota Press.

Cánepa, Gisela. 2011. Introducción. In Imaginario visual y cultura en Perú. Gisela Cánepa K., ed. Pp. 11-60. Lima: Fondo Editorial de la Pontificia Universidad Católica del Perú.

Crafton, Donald. 2004. Collaborative Research, Doc? Cinema Journal 44(1): 138-143.

Elder, Sarah. 1995. Collaborative Filmmaking: an Open Space for Making Meaning, A Moral Ground for Ethnographic Film. Visual Anthropology Review 11(2): 94-101.

Ginsburg, Faye. 2010. Peripheral Visions: Black Screens and Cultural Citizenship. In Cinema at the Periphery. Dina Iordanova, David Martin-Jones and Belen Vidal, eds. Pp. 84-103. Detroit: Wayne State University Press.

Ginsburg, Faye, L. Abu-Lughod, and B. Larkin. 2002. Media Worlds: Anthropology on New Terrain. London: University of California Press.

González Casanova, Pablo. 2003. Colonialismo interno (una redefinición). Revista Rebeldía, No. 12, Instituto de Investigaciones Sociales, Universidad Nacional Autónoma de México (UNAM), México Grau Rebollo, Jorge. 2002. Antropología Audiovisual: Fundamentos teóricos y metodológicos en la inserción del audio-visual en diseños de investigación social. Barcelona: Edicions Bellatierra.

Henley, Paul. 2013. Anthropology: The Evolution of Ethnographic Film. In The Documentary Film Book. Brian Winston ed. British Film Institute. Pp. 309-317 London: Palgrave Macmillan. 
León, Christian. 2010. Reinventando al otro: el documental indigenista en el Ecuador, Quito: Consejo Nacional de Cinematografía.

López, Ana M. 1993. (Not) Looking for Origins: Postmodernism, Documentary, and America. In Theorizing Documentary. Michael Renov ed. Pp. 151-163. New York, London: Routledge.

Lutkehaus, Nancy and Jenny Cool. 1999. Paradigms Lost and Found: 'The Crisis of Representation' and Visual Anthropology. In Collecting Visible Evidence. Jane M. Gaines and Michael Renov, eds. Pp. 116-139. Mineapolis y Londres: University of Minnesota Press.

Mbembe, J. Achiles and Libby Meintjes. 2003. Necropolitics. Public Culture, 15(1): 11-40.

Mignolo, Walter D. 2005. The Idea of Latin America. Oxford: Blackwell.

Mora, Pablo. 2014. Lo propio y lo ajeno del otro cine otro: un panorama de la producción audiovisual indígena de Colombia. In El documental en la era de la complejidad. Christian León, ed. Corporación Cinememoria. Pp. 57-78. Quito: Universidad Andina Simón Bolívar, sede Ecuador. Muratorio, Blanca. 1994. Nación, Identidad y Etnicidad: Imágenes de los indios ecuatorianos y sus imagineros a fines del siglo XIX. In Imágenes e Imagineros: Representaciones de los indígenas ecuatorianos, siglos XIX y XX. Blanca Muratorio, ed. Pp. 109-196. Quito: FLACSO.

Novelo, Victoria. 2001. Video documental en Antropología. Desacatos: Revista de Antropología Social, No. 8: 48-60, Centro de Investigaciones y Estudios Superiores en Antropología Social, CIESAS: Ciudad de México.

O'Brian, Vincent. 2014. Collaborative Visual Ethnography: Practical Issues in Cross-Cultural Research. London: Sage.

Pinney, Christopher. 1992. Future Travel: Anthropology and Cultural Distance in an Age of Virtual Reality; Or, a Past Seen From a Possible Future. Visual Anthropology Review, 8(1): 38-55.

Poole, Deborah. 1997. Vision, Race, and Modernity: A Visual Economy of the Andean Image World. New Jersey: Princeton University Press.

Ramos, Alcida Rita. 1998. Indigenism: ethnic politics in Brazil. Madison: University of Wisconsin Press.

Said, Edward. 1978. Orientalism: Western Representations of the Orient. New York: Pantheon Smith, Linda Tuhiwai. 2012. Decolonizing Methodologies: Research and Indigenous People. London: Zed Books.

Wortham, Erica Cusi. 2013. Indigenous Media in Mexico: Culture Community and the State. Durham y Londres: Duke University Press.

Films

Reis, Luiz Thomaz, dir. 1917. Rituais e festas Borôro (Rituales y Fiestas Bororo). 31 min.

Ruiz, Jorge, dir. 1953. Vuelve Sebastiana (Come Back Sebastiana). 28 min.

Torresan, Angela, dir. 2018. Guto and Graça. $10 \mathrm{~min}$.

Zirión, Antonio, dir. 2001 Chido mi Banda. 18 min.

Zirión, Antonio, dir. 2004 Voces de la Guerrero. $55 \mathrm{~min}$.

Zirión, Antonio, dir. 2013 Fuera de Foco. 37 min. 


\section{NOTES}

1. Although difficult to define precisely, the notion of 'indigenous' refers broadly to groups of individuals who claim a primordial connection to territories and cultures that were forcibly appropriated by European colonialism in Latin America, at different historical times (Wortham 2013). Many elements of indigenism were later extended to other groups defined as subaltern or marginalised.

2. The 5 pages document and its signatories written at the Symposium on Non-Andine South America Interethnic Friction can be consulted at http://www.servindi.org/pdf/ Dec_Barbados_1.pdf

3. Cardús (2014) offers an excelente review of the production of indigenous media projects in Latin America.

4. see Dietrich and Ulfe this issue paragraph 2, 6, 8

5. see Zirión this issue paragraph 47

6. see Flores this issue paragrah 11

\section{INDEX}

Keywords: Latin America, visual anthropology, indigenism, politics and social movement Mots-clés: Amérique Latine, Anthropologie Visuelle, indigénisme, mouvements politiques et sociaux

Palabras claves: Latinoamérica, antropología visual, indigenismo, movimiento político y social

\section{AUTHORS}

\section{CARLOS Y. FLORES}

Universidad Autónoma del Estado de Morelos, México, Department of Anthropology carlosyflores@aol.com

\section{ANGELA TORRESAN}

University of Manchester, Granada Centre for Visual Anthropology

angela.torresan@manchester.ac.uk 